This item was submitted to Loughborough's Research Repository by the author.

Items in Figshare are protected by copyright, with all rights reserved, unless otherwise indicated.

\title{
Caesarean birth and adiposity parameters in 6- to 8-year-old urban Maya children from two cities of Yucatan, Mexico
}

PLEASE CITE THE PUBLISHED VERSION

https://doi.org/10.1002/ajhb.23217

\section{PUBLISHER}

(c) Wiley

\section{VERSION}

AM (Accepted Manuscript)

\section{PUBLISHER STATEMENT}

This is the peer reviewed version of the following article: AZCORRA, H. ... et al, 2019. Caesarean birth and adiposity parameters in 6- to 8-year-old urban Maya children from two cities of Yucatan, Mexico. American Journal of Human Biology, 31 (2), e23217, which has been published in final form at https://doi.org/10.1002/ajhb.23217. This article may be used for non-commercial purposes in accordance with Wiley Terms and Conditions for Use of Self-Archived Versions.

\section{LICENCE}

CC BY-NC-ND 4.0

\section{REPOSITORY RECORD}

Azcorra, Hugo, Luis Rodríguez, Sudip Datta Banik, Barry Bogin, Maria Ines Varela-Silva, and Federico Dickinson. 2019. "Caesarean Birth and Adiposity Parameters in 6- to 8-year-old Urban Maya Children from Two Cities of Yucatan, Mexico". Loughborough University. https://hdl.handle.net/2134/36847. 
Caesarean birth and adiposity parameters in 6-to-8 year-old urban Maya children from two cities of Yucatan, Mexico

Hugo Azcorra1§, Luis Rodríguez², Sudip Datta Banik¹, Barry Bogin³ ${ }^{3}$, Maria Ines Varela-Silva ${ }^{3}$, Federico Dickinson ${ }^{1}$

1: Departamento de Ecología Humana

Centro de Investigación y de Estudios Avanzados del Instituto Politécnico Nacional Mérida, Yucatán, México

Antigua carretera a Progreso Km 6, C.P. 97310

2: Facultad de Matemáticas, Universidad Autónoma de Yucatán, Mérida, Yucatán, México

3: Centre for Global Health and Human Development

School of Sport, Exercise and Health Sciences

Loughborough University, United Kingdom LE11 3TU

$\S$ : corresponding author

\section{hugoazpe@hotmail.com}

The data reported here were collected as part of a project funded by the National Science and Technology Council of Mexico; Consejo Nacional de Ciencia y Tecnología de México (Conacyt). Contract grant number: 168047. 


\section{ABSTRACT}

Objectives: To analyze the association between birth mode and fat mass index (FMI = fat mass $[\mathrm{kg}] /$ height $\left.[\mathrm{m}]^{2}\right)$, and $\mathrm{z}$-score values of waist circumference (WCZ) and sum of triceps and subscapular skinfolds (SumSkfZ) in a sample of 2566 to 8year-old urban Maya children from the cities of Merida and Motul in Yucatan, Mexico.

Methods: From September 2011 to January 2014, we measured height, weight, waist circumference and skinfolds in children and height and weight in their mothers. Body composition was estimated in both generations through bioelectrical impedance analysis. Data on children's birth mode and birth weight were obtained from birth certificates. A pre-validated questionnaire for mothers was used regarding household living conditions. Multiple regression models were used to analyze the association between birth mode and adiposity parameters adjusting for the effect of place of residence, household crowding index, children's birth weight and maternal fat mass (FM). Separate regression models were run for boys and girls.

Results: Caesarean-born children comprised $43 \%$ of the entire sample. Caesarean section (CS) was found to be associated with higher values of body adiposity in girls, but not in boys. Specifically, our models predicted that girls born by CS had an increased value of $0.817 \mathrm{~kg} / \mathrm{m}^{2}$ in FMI and showed higher standard deviations values for WCZ and SumskfZ ( 0.29 and 0.32 SD, respectively) than girls who were delivered vaginally.

Discussion: Our results support the hypothesis that CS is associated with increased levels of adiposity in childhood, but only in girls.

Key words: caesarean birth, adiposity, children, Mexico, Maya 


\section{INTRODUCTION}

The purpose of this paper is to test the hypotheses that birth mode impacts laterlife body fatness in a sample of indigenous Maya people from Mexico. Hypothesis testing in the fields of human biology and public health often excludes indigenous people and other minority populations. Our goal is to broaden the cross-cultural understanding of birth mode and later life health. The rationale behind this approach is that differences in maternal health status and cross-cultural differences in early feeding patterns and obesogenic environments may generate variation in the relationship between birth mode and later body fatness.

Birth is a significant event in the human life cycle (Trevathan, 1987) and birth mode (either vaginal delivery [VD] or caesarean section [CS]) has been shown to have short- and long-term health implications for the babies and their mothers.

Immediately after birth, infants born by CS more frequently show alterations in lung function, thermogenic response, blood pressure and metabolism (Hyde, Mostyn, Modi, \& Kemp, 2012). In terms of future health, CS has been reported to be associated with asthma (Thavagnanam, Fleming, Bromley, Shields, \& Cardwell, 2008), type-I diabetes (Cardwell et al., 2008) and celiac disease (Decker et al., 2010).

Several studies reported an increased risk of overweight and obesity in individuals who were born by CS compared to those born vaginally (Li, Zhou, \& Liu, 2013; Kuhle, Tong, \& Woolcott, 2015). The association between CS and offspring obesity has been examined in many studies, including some where systematic reviews and meta-analyses have been conducted. Kuhle et al. (2015) found that CS was associated with an increased risk of overweight $(\mathrm{OR}=1.34,95 \% \mathrm{Cl} 1.18-1.51)$, when overweight was assessed by Body Mass Index (BMI). This study included 24 studies from 15 countries and focused on children and youths between the ages of 2 and 18 years. Li et al. (2013), also conducted a systematic review and metaanalysis and found that the pooled odds ratio for obesity (also assessed by BMI) in adults born by CS was $1.50(95 \% \mathrm{Cl} 1.02-2.20)$ suggesting that birth mode has long term health implications. 
Most studies reported in these reviews used BMI to characterize risk of overweight and obesity in the populations studied. At least two studies have examined the effect of CS on other parameters of adiposity, such as waist circumference and the sum of triceps plus subscapular skinfolds thickness (Huh et al., 2012; Mesquita et al., 2013) and, again, found that infants and young adults born by CS had higher mean values for waist circumference and skinfold thickness compared to individuals born by VD.

The connection between birth by CS and higher risk for obesity seems to be explained by the characteristics of gut bacterial community established in early stages of development (Stinson, Payne, \& Keelan, 2018). Studies in both humans and mice show that offspring born by CS are less exposed to maternal bacterial flora in the vagina during birth and this in turn alters the composition of their gut microbiota during the first months of postnatal life. Altered gut microbiota profiles in children and adults born by CS are characterized by an increased capacity of energy harvest and low-grade inflammation, factors potentially related to increased adiposity (Manco, Putignani, \& Bottazzo, 2010). Gut microbiota also regulates entero-endocrine cell function influencing the release of several gut hormones that participate in energy store and nutritional balance (Reinhardt, Reigstad, \& Backhed, 2009). In summary, these physiological mechanisms could increase the risk for obese phenotypes. In addition, early microbial colonization by CS can shape successional trajectories in microbial communities (Salminen, Gibson, McCartney, \& Isolauri, 2004), which, in turns, could generate long-lasting effects on phenotype.

The sex of the offspring seems also to be of importance with female offspring being more affected. However, this evidence was gathered from animal models (Martinez et al., 2017) and more research is needed to ascertain if this also happens in humans.

The human samples included in the above-mentioned studies are, however, all from generally well-off populations that represent the majority ethnic group of their country and none has included indigenous populations. Indigenous populations 
tend to have different life history trajectories than non-indigenous due to their exposure to historical trauma, i.e. their systematic and historical segregation, abuse, and unequal access to basic health care and education. This is the case with the Maya people of southern Mexico as documented in many socio-cultural studies (Bracamonte, 2007; Farris, 2012). These negative factors are bound to cause a cascade of influences that perpetuate poor health outcomes in the group (Stephens, Nettleton, Porter, Willis, \& Clark, 2005) both within a single generation and intergenerationally (Drake \& Walker, 2004; Azcorra, Dickinson, Bogin, Rodriguez, \& Varela-Silva, 2015; Azcorra, Dickinson, \& Datta Banik, 2016).

In particular, poverty and food insecurity may predispose individuals to a greater risk of overweight/obesity (Kaur, Lamb, \& Ogden, 2015) and this might even start in the womb. In a study by Singhal and collaborators (2003), poor foetal growth that results in lower birthweight leads to less lean body mass later in life, but it doesn't affect fat mass. This, in turn, may lead to a body composition phenotype that will potentiate the development of cardiovascular diseases. So, it is possible that the impact of delivery mode on phenotype could be exacerbated by the nutritional history of the group.

In fact, indigenous populations are not even regularly included in national health surveys, nor in systematic reviews and meta-analysis (Coimbra et al., 2013). Therefore, despite so many studies in the area, there is a marked gap in the literature regarding birth mode and health outcomes among indigenous groups. Our study aims to start filling this research gap by focusing on the Maya people from Mexico.

The rate of births by CS has increased globally, in particular in low- to middleincome countries including Mexico (Villar et al., 2006; Lumbiganon et al., 2010). According to the 2012 National Survey of Health and Nutrition (ENSANUT as per the Spanish name), in Mexico, the rate of CS was estimated to be $46.9 \%$ overall or up to $70 \%$ in private hospitals (Heredia-Pi, Servan-Mori, Wirtz, Avila-Burgos, \& Lozano, 2014). These figures place Mexico as a country with one of the highest rates of CS in the world. In the southern Mexican state of Yucatan, the rate of CS 
observed during 2008-2015 ranged from $48 \%$ to $53 \%$ (SINAC, 2017) and even the rural Maya women experienced high frequencies of birth by CS. In the same context, Mexico and particularly Yucatan, show alarming rates of overnutrition in children and adults (INSP, 2012). In urban contexts, around $40 \%$ and $80 \%$ of urban Maya children and adults from Yucatan are classified as overweight or obese, respectively (Varela-Silva et al., 2012; Azcorra, Varela-Silva, Rodríguez, Bogin, \& Dickinson, 2013; Méndez et al., 2015).

There is one study exploring the association between birth mode and adiposity outcomes in rural Yucatec-Maya children with minimal exposure to the nutritional transition (Veile \& Kramer, 2016). Here, the authors found that caesarean-born children showed higher average BMI values than vaginally born children. This association was stronger in the presence of mothers with high BMI. It is important to note, however, that the percentage of overweight among the children was low $(5 \%)$ and there were no obese children. This means that BMI variations by birth mode, in this sample, occur within a range capped on the right side of the statistical distribution for $\mathrm{BMI}$, and a longer tail on its left side. The mean z-scores for heightfor-age (HAZ), an indicator of chronic malnutrition or stunting, were very low. Furthermore, vaginally born children showed significantly lower mean HAZ values $(-2.78, S D=1.06)$ than caesarean born children $(-2.59, S D=1.07)$ suggesting that birth mode impacts not only adiposity parameters but also growth in length.

In this study we test the hypothesis that birth by CS is associated with higher body fatness during childhood by using data from a research project that addressed the intergenerational effects and early developmental factors associated with growth and nutritional status in urban Maya families from Yucatan, Mexico. The study of the effect of birth mode on phenotypes provides a useful scenario to analyze the implications of conditions experienced in early stages of development on future health. In this study we aim to analyze the association between birth mode and fat mass index $\left(\mathrm{FMI}=\right.$ fat mass $[\mathrm{kg}] /$ height $\left.[\mathrm{m}]^{2}\right)$, waist circumference and sum of triceps, and subscapular skinfolds in a sample of 256 6- to 8-year old children from the cities of Merida and Motul, in Yucatan, Mexico. 


\section{METHODS}

\section{Ethical clearance}

This research project was reviewed and approved by the Bioethics Committee for the Study of Human Beings of the Center for Research and Advanced Studies of the National Polytechnic Institute (Cinvestav-IPN) of México and the Loughborough University Ethics Advisory Group (R11-P133). Participant mothers signed consent forms and the children gave their verbal assent.

\section{The study location}

The cities of Merida and Motul are in the State of Yucatan, Mexico. Merida is the capital city and represents the most important economic center in the Mexican southeast given its importance in terms of services (education, health and commerce) and infrastructure facilities. By 2015 , Merida was inhabited by 892,363 people (INEGI, 2016), with a Maya population of around 11\% (Lizama Quijano, 2012). The presence of Maya people in Merida corresponds to a process of rural to urban migration that was initiated in the $18^{\text {th }}$ century, during the Spanish Colonial period and the $19^{\text {th }}$ century, after the independence of Mexico, and has intensified since the 1970's. During the last decade, in Merida there have been recorded, on average, 15,000 births per year, of which around $54 \%$ have been through CS. The city of Motul, located in the north-central region of the state at approximately $40 \mathrm{~km}$ from Merida city, was inhabited in 2015 by 36,097 people; $25 \%$ of them were Maya speakers (INEGI, 2016). Nowadays, the economic activities in Motul consist of small-scale livestock production and agriculture, tourism, and maquiladoras (manufacturing operations). In Merida, most of the adult population works as employees and wage labourers in small business performing low wage jobs. In Motul, around 550 births have been registered annually during the last ten years, with a CS frequency of around $49 \%$.

\section{Sample}

The sample size was calculated considering the statistical power. Setting the significance level at $\alpha=0.05$, the power at 0.80 with a medium size error of 0.15 and eight independent variables in a multiple regression model, we found that a sample 
of 107 children and their mothers was required. The final sample consisted of 177 mother-child dyads from Merida and 79 dyads from Motul $(49.6 \%$ girls of both cities). In both cities participants were recruited through primary schools attended by children. In Merida, participants were recruited in 47 schools from low-income neighbourhoods, with a high concentration of Maya speakers, located in several areas of the city. To allow for maximum socioeconomic variability in the sample, we selected no more than ten children from each school. In schools where more than ten children met the inclusion criteria, ten were randomly selected. In the case of Motul, mother-child dyads were recruited in all public primary schools of the city ( $\mathrm{n}$ $=12$ ). The inclusion of participants was based on the following criteria: 1) that children were between 6.0 to 8.9 years of age, 2) the presence of the child's biological mother and 3) that each member of the dyad have paternal and maternal Maya surnames.

\section{Data collection}

From September 2011 to January 2014 we measured height, weight, waist circumference and triceps and subscapular skinfolds in children and height and weight in their mothers. Children were measured in schools during mornings, two hours after breakfast and before any intense physical activity. Mothers were measured during a home visit. Participants were measured by trained research personnel following standardized procedures (Lohman, Roche, \& Martorell, 1998). Body composition was assessed in children and mothers using a bioelectrical impedance analyzer (Bodystat 1500 MDD). In children, body fat mass (FM) was estimated using the equation developed by Ramírez et al. (2012) that was based on a sample of Mexican school children from different geographical regions and ethnicities within the country, using deuterium oxide dilution technique. Fat-free mass (FFM) was calculated using resistance of the bioelectrical impedance, height, and weight values (Equation 1), and then converted to FM (Equation 2) and fat mass index (FMI) (Equation 3). 


\section{Equation 1:}

FFM $(\mathrm{kg})=0.661 \times$ height $(\mathrm{cm})^{2} /$ resistance $(\Omega)+0.200 \times$ weight $(\mathrm{kg})-0.320$

Where $\Omega=$ ohms

Equation 2:

$\mathrm{FM}(\mathrm{kg})=$ weight $(\mathrm{kg})-\mathrm{FFM}(\mathrm{kg})$

Equation 3:

FMI $\left(\mathrm{kg} / \mathrm{m}^{2}\right)=\mathrm{FM}(\mathrm{kg}) /$ height $(\mathrm{m})^{2}$

Body FM in mothers was estimated with an equation developed by Macias et al. (2007) based on a sample of 20 to 50-year-old Mexican women from low, middle, and upper income levels. The predictive equation for bioelectrical impedance was developed using air displacement plethysmography as a standard method to measure body composition. Accordingly, FFM was computed using height, weight, resistance and reactance of bioelectrical impedance and age of adult women (Equation 4), and then was converted to FM (Equation 5).

\section{Equation 4:}

Mothers' FFM $(\mathrm{kg})=0.7374 \times$ [height $(\mathrm{cm})^{2} /$ resistance $\left.(\Omega)\right]+0.1763 \times$ [weight $(\mathrm{kg})]-0.1773 \times$ [age (years) $]+0.1198 \times[$ reactance $(\Omega)]-2.4658$

Where $\Omega=$ ohms

Equation 5:

Mothers' FM $(\mathrm{kg})=$ weight $(\mathrm{kg})-$ FFM $(\mathrm{kg})$

Body mass index (BMI) was calculated in children and adult women only for descriptive purposes. Percentiles and z-scores by children's age and sex were calculated for height (HAZ), BMI (BMIZ), waist circumference (WCZ) and sum of skinfolds (SumSkFZ) using the growth reference data published by Frisancho (2008). Stunting (low height-for-age) was defined in children and mothers based on a HAZ below the $5^{\text {th }}$ percentile (or a $z$-score $\leq-1.650$ ) in the reference data. Values of reference data for BMIZ, WCZ and SumSkfZ above the $85^{\text {th }}$ percentile (or a zscore $>+1.036$ ) were used to define BMI-based excess weight (overweight + obesity) in children and also for high body fatness estimated by waist circumference and SumSkf. Excess weight in mothers was defined as a BMI 
greater than $25 \mathrm{~kg} / \mathrm{m}^{2}$ (WHO, 1995). Growth reference values for FM/FMl are not available for Mexican populations.

During the home visit, a pre-validated questionnaire for mothers was used regarding household living conditions. We recorded data on family size and number of bedrooms to calculate crowding index. Overcrowding in the home has been shown to be the indicator that best expresses the variation in the living conditions in urban Maya families (Azcorra, Datta Banik, \& Dickinson, 2016). Data on children's birth mode (VD vs CS) and birth weight data were obtained from birth certificates provided by mothers.

\section{Data analyses}

Student's $t$-tests were used to test differences in mean values of children's anthropometric and body composition characteristics and derived variables by sex and birth mode. Chi-square tests were used to compare the proportions of children's nutritional status categories between groups of birth mode. Normality in the distribution of outcome variables was analyzed graphically through probability plots. The association between CS and child's adiposity was analyzed through multiple linear regression models. Outcome variables were $\mathrm{FMI}\left(\mathrm{kg} / \mathrm{m}^{2}\right), W C Z$ and SumSkfZ. Separate regression models were run for boys and girls. Models for FMI were adjusted for place of residence (Merida vs Motul), household crowding index, child's age, birth weight and maternal FM. Models for WCZ and SumSkfZ were adjusted for the same variables, except for child's age since z-scores already take age into account. The exposure factor was CS. Interactions were statistically tested between CS and maternal FM and child's birth weight. Diagnostic tests were applied to determine model validity. Possible departures from the statistical assumptions were explored through diagnostic plots of residuals; all of these supports the appropriateness of the regression models for the data. Data entry and analysis were made with Stata/IC 11.1 for Windows statistical package (StataCorp LP, 2010). The significance level for statistical tests was $\alpha=0.05$. 


\section{RESULTS}

Mean age of children and mothers was $7.54(S D=0.83)$ and $32.99(S D=5.53)$ years, respectively. Caesarean-born children comprised $43 \%$ of the entire sample.

\section{Anthropometric characteristics and nutritional status of participants}

Twelve percent of children met the criteria for stunting and $37 \%, 32 \%$ and $26 \%$ exhibited excess values of BMI, WC and SumSkf according to their age and sex, respectively. Girls showed significantly higher values of WCZ and SumSkfZ than boys. Mean birth weight for all children was $3126 \mathrm{~g}(\mathrm{SD}=502)$. The mean value of maternal height was $147.80 \mathrm{~cm}(\mathrm{SD}=4.95)$ and $73 \%$ of mothers were below the $5^{\text {th }}$ percentile $(150 \mathrm{~cm})$ of the growth reference, while $86 \%$ of mothers had a BMI above $25 \mathrm{~kg} / \mathrm{m}^{2}$ and their average body FM was $26 \mathrm{~kg}$ (SD = 7.60). Mothers of boys and girls born by CS were significantly shorter than mothers of children born vaginally.

\section{Caesarean section and children's adiposity}

Girls born by CS showed significantly higher values in SumSkfZ than those vaginally delivered and differences in FMI and WCZ were nearly significant ( $p=$ 0.054 and $p=0.065$, respectively). Caesarean-born girls showed a significantly higher proportion of exceeded values of SumSkf (above $85^{\text {th }}$ percentile) than those vaginally delivered (Table 1). Boys born by CS and VD were similar in all adiposity parameters and categories of nutritional status.

\section{TABLE 1 HERE}

Results of multiple regression models for outcome variables are shown in Table 2. After adjusting for the effect of covariates, CS delivery was associated with higher values in all adiposity parameters in girls. Specifically, regression models showed that girls born by CS had $0.817 \mathrm{~kg} / \mathrm{m}^{2}$ higher FMI and were 0.29 and 0.32 standard deviations higher in waist circumference and sum of skinfolds respectively than girls delivered vaginally. In boys, CS was not statistically associated with adiposity parameters.

\section{TABLE 2 HERE}




\section{DISCUSSION}

Excess body weight is a widespread condition among children and their mothers in this sample of urban Maya families from Yucatan. Our results support the hypothesis that CS is associated with increased levels of adiposity in childhood, but only in girls.

There are few studies on the relationship between CS and indicators of adiposity. In a study among young adults (23 to 25 years of age) from the 1978/79 Ribeirão Preto Birth Cohort from Brazil, Mesquita and collaborators (2013) reported that individuals born by CS had an increased risk for having higher mean values of waist circumference ( $\geq 90 \mathrm{~cm}$ for men and $\geq 80 \mathrm{~cm}$ for women), WHtR (>0.5), waistto-hip ratio ( $\geq 0.90$ for men and $\geq 85$ for women) and triceps and subscapular skinfolds ( $>90^{\text {th }}$ percentile). These results were found after controlling for the effect of individuals' birth weight and sex, maternal age, parity, schooling, smoking during pregnancy and gestational age. Likewise, studying children enrolled in the Project Viva in Massachusetts in the United States at the age of 3 years, Hu and coworkers (2012) found that CS was associated with higher skinfold thicknesses (0.94 mm; $95 \% \mathrm{Cl}, 0.36-1.51 \mathrm{~mm}$ ). In the context of our sample, CS was associated with higher levels of FMI, sum of triceps and subscapular skinfolds and waist circumference, measures for total body fat and estimates of subcutaneous and deep adipose tissues, respectively.

The effect of birth by CS on phenotype has been previously analyzed in the Maya population. Studying a longitudinal sample of 108 children aged 0 to 5 years from an agricultural community from Yucatan, Veile and Kramer (2016) found that birth by CS was a significant predictor of higher z-score values of weight-for-age and BMI-for-age indicators after adjusting for children's sex, age and birthweight and maternal BMI. More pronounced differences in growth trajectories according to birth mode were found in children whose mothers had higher values of BMI and in children with higher birth weights. In our study, there was no association between birth mode and mother's FM and children birth weight and these results might be explained by the fact that mothers from Merida and Motul have on average higher 
values of BMI than women studied by Veile and Kramer in the rural Yucatan (mean $=29.74 \mathrm{~kg} / \mathrm{m}^{2},[\mathrm{SD}=4.73]$ vs mean $\left.=27.38 \mathrm{~kg} / \mathrm{m}^{2}[\mathrm{SD}=3.56], \mathrm{p}<0.001\right)$.

Regression models showed a positive association between CS and adiposity in girls. Birth weight and maternal FM of girls did not differ according to their birth mode, which suggests that association between CS and outcome variables in this sex group is not explained by these factors. None of the studies on the relationship between CS and indicators of adiposity cited above report sex differences in the effect of CS. There is some evidence in non-human animals that CS has a differential effect on phenotype between males and females. Investigating the impact of CS on body weight gain and gut microbiota during early development in mice, Martinez and collaborators (2017) found that CS delivered mice showed higher post-weaning mass gain than VD controls. In both sexes, mice gained $33 \%$ more weight at age 15 weeks if they were born by CS, but female mice showed an increased influence with $70 \%$ higher weight gain.

Why were CS deliveries positively associated with greater adiposity levels in girls, but not in boys? Studies in humans and mice suggest that differences in endocrine and immune systems between sexes induce different gut microbiota profiles in males and females (Fransen et al., 2017). Studies have demonstrated sexual dimorphism in several aspects of gut microbiota, including their composition (Dominianni et al., 2015; Mueller et al., 2006; Li et al., 2008), their changes in response to factors such as diet (Bolnick et al., 2014; Karunasena, McMahon, Chang, \& Brashears, 2014) and their diversity, structure and individual phylotype during the colonization in germ-free mice (Wang et al., 2016). Females have consistently shown lower abundance of Bacteroidetes in their microbiota, a group of bacteria with beneficial effects in metabolism (Dominianni et al., 2015; Mueller et al., 2006). More importantly sex differences in gut microbiota have shown to play a key role in sex-related diseases (Markle et al., 2013; Yurkovetskiy et al., 2013). A recent study with mice found that a transfer of male microbiome to females drove testosterone-dependent attenuation of autoimmune phenotypes and protection from Type I Diabetes (Markle et al., 2013). It has been proposed that gender 
differences in the immune system select a genus-specific intestinal microbiota composition, which in turn contributes to gender differences in the immune system (Fransen et al., 2017). In the context of our study, it is possible that higher adiposity levels shown by female offspring in response to caesarean delivery is due to the early configuration of a gut microbiota with less beneficial characteristics in terms of metabolism, in comparison to male offspring. In the study of Martinez and collaborators (2017) cited above, the researchers also found that mice delivered by CS showed a lower diversity in their microbiota at weaning and showed no major changes in microbiome maturity during the four weeks after weaning.

The positive association between CS and levels of fatness in girls, but not in boys, has not been reported in other studies with human samples. Unfortunately, at this point we are unable to explain why it is the case in our data. This fact calls for further research to find the effects of CS on body composition of male and female offspring and the mechanisms that could explain the possible differences between sexes.

Consistent with the global tendency, the rate of CS in this sample was high (43\%). Several factors have been associated with high rates of CS. It has been showed that the dual burden of malnutrition -the coexistence of short stature and overweight/obesity- exacerbate obstetric complications through influences on maternal phenotype and new-born size (Wells, Wibaek, \& Poullas, 2018). Almost $63 \%$ of mothers of this sample exhibited short stature and high BMI. Mothers of children born by CS were shorter than mothers of vaginally delivered children and this finding is consistent with several studies that show a negative association between maternal height and incidence of CS (Mahmood, Campbell, \& Wilson, 1988; McGuinness \& Trivedi, 1999; Prasad \& Al-Taher, 2002; Okewole et al., 2011; Stulp, Verhulst, Pollet, Nettle, \& Buunk, 2011; Benjamin, Daniel, Kamath, \& Ramkumar, 2012). Maternal height has been shown to be positively correlated with pelvic measurements (Mahmood et al., 1988; Adadevoh, Hobbs, \& Elkins, 1989) and this in turn may contribute to the increased incidence of CS deliveries due to 
cephalopelvic disproportion (Benjamin et al., 2012). On the other hand, maternal obesity before and during pregnancy are related to obstetric complications due to increased CS frequency (Weiss et al., 2004) and exposes the foetus to high levels of nutrients, increasing the risk of high birth weights.

\section{Strengths and limitations}

In this study we analyzed the effect of births by CS on more direct parameters of adiposity; most of available studies in children use the indirect measure of body mass index as a proxy for overweight/obesity. Body mass index was used in this study only to describe the nutritional status of mothers and their children. Regarding the limitations of this study, we lack information on children's diet and energy expenditure which would better explain variation in child adiposity. The cross-sectional nature of this study is another limitation, further research is needed to investigate the effect of CS on body fat gain during infancy and childhood.

\section{Conclusion}

The results of this study show the frequency of CS among the urban Maya population from Merida, Mexico, is high. Our analyses show that CS delivery is associated with higher values of FMI and z-score values of waist circumference and sum of triceps and subscapular skinfolds in children, but only in female offspring and this finding is not explained by differences in birth weight and maternal fat mass. It is possible that higher adiposity levels shown by female offspring in response to caesarean delivery is due to the early configuration of a gut microbiota with less beneficial characteristics in terms of metabolism.

In a broader context, our results contribute to the discussion on the implications of rising caesarean birth rates on short and long-term offspring health outcomes. It is important to recognize that while caesarean deliveries may save a significant number of lives of mothers and babies, particularly in populations with high risk of perinatal morbidity and mortality, they also have some negative consequences on population health and wellbeing, in the short and long term. 


\section{ACKNOWLEDGEMENTS}

The authors thank those who assisted in the field work, especially Ms. Graciela Valentín Sánchez and Ms. Adriana Vázquez-Vázquez for taking anthropometric measurements, applying questionnaires and organizing the field work. Additional field work assistance was provided by Ms. Paulina Cauich, Ms. Frida Gutiérrez and Ms. Samantha Sánchez. We very much appreciate the mothers and their children who agreed to participate in the study.

The authors declare no conflict of interest.

\section{AUTHOR CONTRIBUTIONS}

HA formulated the research question and wrote the first draft of the manuscript. HA and LR analyzed the data. BB, FD, SDB and IVS contributed to the creative process of this paper by providing scientific content and intellectual additions on the subsequent drafts of the manuscript.

\section{LITERATURE CITED}

Adadevoh, S. W., Hobbs, C., \& Elkins, T. E. (1989). The relationship of the true conjugate to maternal height and obstetric performance in Ghanaians. International Journal of Gynaecology and Obstetrics. 28(3), 243-251.

Azcorra, H., Dickinson, F., Bogin, B., Rodriguez, L., \& Varela-Silva, M. I. (2015). Intergenerational influences on the growth of Maya children: The effect of living conditions experienced by mothers and maternal grandmothers during their childhood. American Journal of Human Biology. 27(4), 494-500.

Azcorra, H., Dickinson, F., \& Datta Banik, S. (2016). Maternal height and its relationship to offspring birth weight and adiposity in 6- to 10-year-old Maya children from poor neighbourhoods in Merida, Yucatan. American Journal of Physical Anthropology. 161(4), 571-571. 
Azcorra, H., Varela-Silva, M. I., Rodríguez, L., Bogin, B., \& Dickinson, F. (2013).

Nutritional status of Maya children, their mothers, and their grandmothers residing in the city of Merida, Mexico: revisiting the leg-length hypothesis. American Journal of Human Biology. 25(5), 659-665.

Benjamin, S. J., Daniel, A. B., Kamath, A., \& Ramkumar, V. (2012). Anthropometric measurements as predictors of cephalopelvic disproportion: Can the diagnostic accuracy be improved? Acta Obstetricia et Gynecolica Scandinavica. 91(1), 122127.

Bolnick, D. I., Snowberg, L. K., Hirsch, P. E., Lauber, C. L., Org, E., Parks, B., ...Svanbäck, R. (2014). Individual diet has sex-dependent effects on vertebrate gut microbiota. Nature Communications. 5, 4500.

Bracamonte, P. (2007). Una deuda histórica. Ensayo sobre las causas de pobreza secular de los mayas yucatecos. México, DF: CIESAS-Porrúa-ICY.

Cardwell, C. R., Stene, L. C., Joner, G., Cinek, O., Svensson, J., Goldacre, M. J., ... Patterson, C. C. (2008). Caesarean section is associated with an increased risk of childhood-onset type 1 diabetes mellitus: a meta-analysis and observational studies. Diabetologia. 51(5), 726-735.

Coimbra, C. E., Santos, R. V., Welch, J. R., Cardoso, A. M., de Souza, M. C., Garnelo, L., ... Horta, B. L. (2013). The first National Survey of Indigenous People's Health and Nutrition in Brazil: rationale, methodology, and overview of results. BMC Public Health. 13:52.

Decker, E., Engelman, G., Findeisen, A., Gerner, P., Laass, M., ... Hornef, M. W. (2010). Cesarean delivery is associated with celiac disease but not inflammatory bowel disease in children. Pediatrics. 125(6), e1433-1440. 
Dominianni, C., Sinha, R., Goedert, J., Pei, Z., Yang, L., Hayes, R. B., \& Ahn, J. (2015). Sex, body mass index, and dietary fiber intake influence the human gut microbiome. Plos One. 10, e0124599.

Drake, A. J., Walker, B. R. (2004). The intergenerational effects of fetal programming: non-genomic mechanisms for the inheritance of low birth weight and cardiovascular risk. Journal of Endocrinology. 180(1): 1-16.

Farris, N. (2012). La sociedad maya bajo el dominio colonial. México, DF: Instituto Nacional de Antropología e Historia. Original English version: Maya Society under Colonial Rule. The Collective Enterprise of Survival, Princeton University Press, 1984.

Fransen, F., van Beek, A. A., Borghuis, T., Meijer, B., Hugenholtz, F., van der Gaast-de Jongh, C., ... de Vos, P. (2017). The impact of gut microbiota on genderspecific differences in immunity. Frontiers in immunology. 8:754.

Frisancho, A. R. (2008). Anthropometric standards: an interactive nutritional reference of body size and body composition for children and adults. Ann Arbor: The University of Michigan Press.

Heredia-Pi, I., Servan-Mori, E. E., Wirtz, V. J., Ávila-Burgos, L., \& Lozano, R. (2014). Obstetric care and method of delivery in Mexico: results from the 2012 National Health and Nutrition Suvey. PLos ONE. 9(8), e104166.

Huh, S. Y., Rifas-Shaman, S. L., Zera, C. A., Edwards, J. W., Oken, E., Weiss, S. T., \& Gillman, M. W. (2012). Delivery by caesarean section and risk of obesity in preschool age children: a prospective cohort study. Archives of Disease in Childhood. 97(7), 610-616. 
Hyde, M. J., Mostyn, A., Modi, N., \& Kemp, P. R. (2012). The health implications of birth by caesarean section. Biological Reviews of the Cambridge Philosophical Society. 87(1), 229-243.

INEGI. (2016). Encuesta Intercensal 2015. Panorama sociodemográfico de Yucatán. México: Instituto Nacional de Estadística y Geografía. 2016. Retrieved from

http://www3.inegi.org.mx/sistemas/Panorama2015/Web/Contenido.aspx\#Yucatán3 $\underline{1000}$

INSP. (2012). Encuesta Nacional de Salud y Nutrición 2012. Resultados por entidad federativa, Yucatán. Cuernavaca, México: Instituto Nacional de Salud Pública, 2013. Retrieved from encuestas.insp.mx.

Karunasena, E., McMahon, K. W., Chang, D., \& Brashears, M. M. (2014). Hot responses to the pathogen Mycobacterium avium subsp. paratuberculosis and beneficial microbes exhibit host sex specificity. Applied and Environmental Microbiology. 80, 4481-4490.

Kaur, J., Lamb, M. M., \& Ogden, C. L. (2015). The association between food insecurity and obesity in children - The National Health and Nutrition Examination Survey. Journal of the Academy of Nutrition and Dietetics. 115(5), 751-758.

Kuhle, S., Tong, O. S., \& Woolcott, C. G. (2015). Association between caesarean section and childhood obesity: A systematic review and meta-analysis. Obesity Reviews. 16(4), 295-303.

Li, H. T., Zhou, Y. B., \& Liu, J. M. (2013). The impact of caesarean section on offspring overweight and obesity: A systematic review and meta-analysis. International Journal of Obesity. 37(7), 893-899. 
Li, M., Wang, B., Zhang, M., Rantalainen, M., Wang, S., Zhou, H., ...Zhao, L. (2008). Symbiotic gut microbes modulate human metabolic phenotypes.

Proccedings of the National Academy of Sciences of the United States of America. 105, 2117-2122.

Lizama Quijano, J. J. (2012). Del Pueblo a la Urbe. El Perfil Maya de la Blanca Mérida. México: Centro de Investigaciones y de Estudios Superiores en Antropología Social.

Lohman, T. G., Roche, A. F., \& Martorell, R. (1988). Anthropometric standardization reference manual. Champaign: Human Kinetics Books.

Lumbiganon, P., Laopaiboon, M., Gülmezoglu, A. M., Souza, J. P., Taneepanichskul, S., Ruyan, P., ... Villar, J. (2010). Method of delivery and pregnancy outcomes in Asia: The WHO global survey on maternal and perinatal health 2007-08. Lancet. 375(9713), 490-499.

Macias, N., Alemán-Mateo, H., Esparza-Romero, J., \& Valencia, M. E. (2007). Body fat measurement by bioelectrical impedance and air displacement plethysmography: a cross-validation study to design biolectrical impedance equations in Mexican adults. Nutrition Journal. 2007, 15(6):18.

Mahmood, T. A., Campbell, D. M., \& Wilson, A. W. (1988). Maternal height, shoe size, and outcome of labour in white primigravidas: a prospective anthropometric study. British Medical Journal. 297(6647), 515-517.

Manco, M., Putignani, L., \& Bottazzo, G. F. (2010). Gut microbiota, lipopolysaccharides of obesity and cardiovascular risk. Endocrine Reviews. 31(6), 817-844. 
Markle, J. G. M., Frank, D. N., Mortin-Toth, S., Robertson, C. E., Feazel, L. M., Rolle-Kampczyk, U., ...Danska, J. S. (2013). Sex differences in the gut microbiome drive hormone-dependent regulation of autoimmunity. Science. 339(6123):10841088.

Martinez II, K. A., Devlin, J. C., Lacher, C. R., Yin, Y., Cai, Y., Wang, J., \& Dominguez-Bello, M. G. (2017). Increased weight gain by C-section: Functional significance of the primordial microbiome. Science Advances. 3,eaao1874.

McGuinness, B. J., \& Trivedi, A. N. (1999). Maternal height as a risk factor for caesarean section due to failure to progress in labour. Australian and New Zealand Journal of Obstetrics and Gynaecology. 39(2), 152-154.

Méndez, N., The Late Mario Barrera-Pérez, Palma-Solis, M., Zavala-Castro, J., Dickinson, F., Azcorra, H., \& Prelip, M. (2015). Ethnicity and income impact on BMI and stature of school children living in urban southern Mexico. Journal of Biosocial Science. 48(2), 143-157.

Mesquita, D. N., Barbieri, M. A., Goldani, H. A., Cardoso, V. C., Goldani, M. Z., Kac, G., Silva, A. A., \& Bettiol, H. (2013). Caesarean section is associated with increased peripheral and central adiposity in young adulthood: cohort study. PLoS ONE. 8(6), e66827.

Mueller, S., Saunier, K., Hanisch, C., Norin, E., Alm, L., Midtvedt, T., ...Blaut, M. (2006). Differences in fecal microbiota in different European study populations in relation to age, gender, and country: a cross-sectional study. Appl Environ Microbiol. 72, 1027-1033.

Okewole, I. A., Faiola, S., Fakounde, A., Yoong, W., Phillip, H., \& Amer, S. (2011). The relationship of ethnicity, maternal height and shoe size, and method of delivery. Journal of Obstetrics and Gynaecology. 31(7), 608-611. 
Prasad, M., \& Al-Taher, H. (2002). Maternal height and labour outcome. Journal of Obstetrics and Gynaecology. 22(5), 513-515.

Ramírez, E., Valencia, M. E., Bourges, H., Espinosa, T., Moya-Camarena, S. Y., Salazar, G., \& Alemán-Mateo, H. (2012). Body composition prediction equations based on deuterium oxide dilution method in Mexican children: a national study. European Journal of Clinical Nutrition. 66(10),1099-1103.

Reinhardt, C., Reigstad, C. S., \& Backhed, F. (2009). Intestinal microbiota during infancy and its implications for obesity. Journal of Pediatric Gastroenterology and Nutrition. 48(3), 249-256.

Salminen, S., Gibson, G. R., McCartney, A. L., \& Isolauri, E. (2004). Influence of mode of delivery on gut microbiota composition in seven year old children. Gut. 53(9), 1388-1389

SINAC. (2017) Subsistema de Información sobre Nacimientos-SINAC. Yucatán. Available at http://www.dgis.salud.gob.mx/contenidos/basesdedatos/std nacimientos gobmx.ht ml consulted on February 2018.

Singhal, A., Wells, J., Cole, T. J., Fewtrell, M., \& Lucas, A. (2003). Programming of lean body mass: a link between birth weight, obesity, and cardiovascular disease. American Journal of Clinical Nutrition. 77(3), 726-730.

Stephens, C., Nettleton, C., Porter, J., Willis, R., \& Clark, S. (2005). Indigenous peoples' health-why are they behind everyone, everywhere? Lancet. 366 (9479), 10-13. 
Stinson, L. F., Payne, M. S., \& Keelan, J. A. (2018). A Critical review of the bacterial baptism hypothesis and the impact of cesarean delivery on the infant microbiome. Frontiers in Medicine. 5(135).

Stulp, G., Verhulst, S., Pollet, T. V., Nettle, D., \& Buunk, A. P. (2011). Parental height differences predict the need for an emergency caesarean section. PLos ONE. 6(6), e20497.

Thavagnanam, S., Fleming, J., Bromley, A., Shields, M. D., \& Cardwell, C. R. (2008). A meta-analysis of the association between caesarean section and childhood asthma. Clinical \& Experimental Allergy. 38(4), 629-633.

Trevathan, W. R. (1987). Human Birth. An Evolutionary Perspective. New York: Aldine de Gruyter.

Varela-Silva, M. I., Dickinson, F., Wilson, H., Azcorra, H., Griffiths, P. L., \& Bogin, B. (2012). The nutritional dual-burden in developing countries - How is it assessed and what are the health implications? Collegium Antropologicum.36(1), 39-45.

Veile, A., \& Kramer, K. L. (2016). Childhood body mass is positively associated with cesarean birth in Yucatec Maya subsistence farmers. American Journal of Human Biology. 29(2), 9-13.

Villar, J., Valladares, E., Wojdyla, D., Zavaleta, N., Carroli, G., Velazco, A., ...Acosta, A. (2006). Caesarean delivery rates and pregnancy outcomes: The 2005 WHO global survey on maternal and perinatal health in Latin America. Lancet. 367(9525), 1819-1829.

Wang, J., Wang, J., Pang, X., Zhao, L, Tian, L, \& Wang, X. (2016). Sex differences in colonization from a man with short-term vegetarian and inulin-supplemented diet in germ-free mice. Scientific Reports. 6:36137. 
Weiss, J. L., Malone, F. D., Emig, D., Ball, R. H., Nyberg, D. A., Comstock, C. H., ...D'Alton, M. E. (2004). Obesity, obstetric complications and caesarean delivery rate- A population-based screening study. American Journal of Obstetrics and Gynecology. 190(4), 1091-1097.

Wells, J. C. K., Wibaek, R., \& Poullas, M. (2018). The dual burden of malnutrition increases the risk of cesarean delivery: evidence from India. Frontiers in Public Health. 6, 292.

WHO. Physical status: the use and interpretation of anthropometry. Report of a WHO Expert Committee. WHO Technical Report Series 854. 1995. Geneva: World Health Organization.

Yurkovetskiy, L., Burrows, M., Khan, A. A., Graham, L., Volchkov, P., Becker, L., ...Chervonsky, A. V. (2013). Gender bias in autoimmunity is influenced by microbiota. Immunity. 39:400-41 
TABLE 1 Descriptive statistics of anthropometric, body composition characteristics and derived variables of mothers and children according to child birth mode by sex

\begin{tabular}{|c|c|c|c|c|c|c|c|c|c|c|}
\hline \multirow[b]{3}{*}{ Variable } & \multicolumn{5}{|l|}{ Boys } & \multicolumn{5}{|l|}{ Girls } \\
\hline & \multicolumn{2}{|c|}{$\operatorname{VD}(n=71)$} & \multicolumn{2}{|c|}{$\operatorname{CS}(n=58)$} & \multirow[b]{2}{*}{$P$-value } & \multicolumn{2}{|c|}{$\operatorname{VD}(n=76)$} & \multicolumn{2}{|c|}{$\operatorname{CS}(n=51)$} & \multirow[b]{2}{*}{$P$-value } \\
\hline & Mean & SD & Mean & SD & & Mean & SD & Mean & SD & \\
\hline \multicolumn{11}{|l|}{ Mothers } \\
\hline Age (years) & 33.17 & 5.04 & 32.29 & 5.28 & 0.339 & 32.67 & 5.74 & 33.66 & 6.01 & 0.354 \\
\hline Height (cm) & 148.39 & 4.58 & 146.27 & 4.36 & 0.019 & 149.40 & 4.05 & 146.53 & 4.76 & $<0.001$ \\
\hline BMI $\left(\mathrm{kg} / \mathrm{m}^{2}\right)$ & 29.76 & 4.68 & 30.21 & 5.04 & 0.603 & 29.97 & 4.80 & 29.00 & 4.47 & 0.256 \\
\hline $\mathrm{FM}(\mathrm{kg})$ & 26.57 & 6.98 & 25.46 & 7.14 & 0.402 & 26.64 & 7.94 & 25.07 & 7.69 & 0.268 \\
\hline \multicolumn{11}{|l|}{ Children } \\
\hline Age (years) & 7.57 & 0.83 & 7.59 & 0.92 & 0.888 & 7.55 & 0.82 & 7.44 & 0.77 & 0.472 \\
\hline Birth weight (g) & 3164 & 398 & 3086 & 467 & 0.383 & 3142 & 403 & 3056 & 496 & 0.354 \\
\hline Height (z-score) & -0.70 & 0.81 & -0.57 & 0.94 & 0.427 & -0.57 & 0.93 & -0.45 & 0.83 & 0.451 \\
\hline BMI (z-score) & 0.82 & 0.99 & 1.04 & 1.00 & 0.243 & 0.58 & 0.96 & 0.91 & 1.00 & 0.068 \\
\hline WC (z-Score) & 0.51 & 0.83 & 0.65 & 0.82 & 0.368 & 0.66 & 0.77 & 0.92 & 0.77 & 0.065 \\
\hline SumSkf (z-Score) & 0.30 & 0.83 & 0.43 & 0.86 & 0.398 & 0.54 & 0.79 & 0.85 & 0.80 & 0.038 \\
\hline FMI $\left(\mathrm{kg} / \mathrm{m}^{2}\right)$ & 5.45 & 2.02 & 5.78 & 2.27 & 0.375 & 5.67 & 2.08 & 6.42 & 2.18 & 0.054 \\
\hline \multicolumn{11}{|l|}{ Nutritional status } \\
\hline Exceeded BMI ( $\geq 85$ th percentile) & \multicolumn{2}{|c|}{$38 \%$} & \multicolumn{2}{|c|}{$41 \%$} & $\mathrm{X}_{(1)}^{2}=0.150, P=0.699$ & \multicolumn{2}{|c|}{$29 \%$} & \multicolumn{2}{|c|}{$41 \%$} & $\mathrm{X}_{(1)}^{2}=2.04, P=0.153$ \\
\hline Exceeded WC ( $\geq 85$ th percentile) & \multicolumn{2}{|c|}{$31 \%$} & \multicolumn{2}{|c|}{$28 \%$} & $\mathrm{X}_{(1)}^{2}=0.178, P=0.673$ & \multicolumn{2}{|c|}{$30 \%$} & \multicolumn{2}{|c|}{$45 \%$} & $\mathrm{X}_{(1)}^{2}=2.91, P=0.088$ \\
\hline Exceeded SumSkf ( $\geq 85$ th percentile) & \multicolumn{2}{|c|}{$21 \%$} & \multicolumn{2}{|c|}{$22 \%$} & $\mathrm{X}_{(1)}^{2}=0.031, P=0.860$ & \multicolumn{2}{|c|}{$25 \%$} & \multicolumn{2}{|c|}{$42 \%$} & $\mathrm{X}_{(1)}^{2}=4.02, P=0.045$ \\
\hline
\end{tabular}

BMI, body mass index; CS, caesarean section; FM, fat mass; FMI, fat mass index; SD, standard deviation; Stunting, low height-for-age; SumSkf, sum of skinfold (triceps, subscapular and suprailiac); VD, vaginal delivery; WC, waist circumference.

TABLE 2 Regression models relating caesarean section to children's fat mass index, waist circumference and sum of triceps and subscapular skinfolds, by sex

\begin{tabular}{|c|c|c|c|c|c|c|}
\hline \multirow[b]{2}{*}{ Variable } & \multicolumn{3}{|l|}{ Boys } & \multicolumn{3}{|l|}{ Girls } \\
\hline & B (SE) & $95 \%$ CI & $P$-value & B (SE) & $95 \%$ CI & $P$-value \\
\hline Fat mass index $\left(\mathrm{FMI}=\mathrm{kg} / \mathrm{m}^{2}\right)$ & $0.275(0.331)$ & -0.380 .93 & 0.409 & $0.817(0.373)$ & 0.081 .56 & 0.031 \\
\hline Waist circumference (z-score) & $0.143(0.141)$ & -0.140 .42 & 0.312 & $0.295(0.141)$ & 0.020 .57 & 0.038 \\
\hline Sum of skinfolds (z-score) & $0.128(0.144)$ & -0.160 .41 & 0.377 & $0.324(0.146)$ & 0.030 .61 & 0.028 \\
\hline
\end{tabular}

Models for FMI were adjusted for location (Merida vs Motul), household crowding index, children's age (years) and birth weight (g), and matemal body fat mass (kg); models for waist circumference and sum of skinfolds were adjusted for the same variables except for children's age.

SE, standard error. 